\title{
Dylan Thomas's 25 Poems: Paradox as Structure
}

\author{
S.BHARADWAJ \\ Annamalai University, Tamilnadu. India \\ E-mail: mithrabharath@yahoo.in
}

Doi:10.7575/aiac.alls.v.5n.6p.153

URL: http://dx.doi.org/10.7575/aiac.alls.v.5n.6p.153
Received: $19 / 08 / 2014$

Accepted: 07/10/2014

\begin{abstract}
Irony, inclusiveness, and complexity are the chief criteria of value in the twentieth century intellectual poetry. These criteria, however, do not merely indicate qualities of craftsmanship; they reflect a sensibility, a particular way of experiencing reality. What really distinguishes Dylan Thomas is a capacity for self-analysis, a capacity for objectifying, and subjecting to analytical scrutiny, one's own experiences and feelings. The searching self-exploration that links Thomas with W.H. Auden is more evident in 25 Poems than in his 18 Poems, and in 25 Poems the readers are priviledged to watch his own mental processes. What happens in 18 Poems is that the poet's mind operates simultaneously at two levels, and the readers can witness a co-operation and coalescence of emotion and ratiocination. In 25 Poems, the heart is involved in experience and suffers, while an alert intelligence, conscious of itself, analyses and weighs the experience. The result is inclusiveness arising out of a recognition of the complexity of experience, of the pressure of the total context upon a particular situation or mental state. Thomas's 18 Poems has this quality of paradox in varying degrees, and it shows the juxtaposition and integration of opposed attitudes enriching the poetic texture. The most equal emphases on erotic love and creative quest in 18 Poems present one kind of inclusiveness. In 25 Poems, the apparently disorganized flow of thought resembles the stream-of-consciousness technique, but the presence of an alert mind weighing different approaches and directing the journey of life is obvious. His interest in Day Lewis, Spender, and MacNeice is equally indicative of his love of contrasts, of chiaroscuro effects, and is not to be confused with Auden's interest in characterization. Thomas's early poetry is an imago of paradox, "a home" of "comfort" and faith "the neighbour's strongest wish, to serve and love..." in which "no one but myself is loved".
\end{abstract}

Keywords: Paradox, cerebral, irony, affective, analogous, and crusade.

\section{Introduction}

From the middle of February to the middle of October of 1936 was a blank period--"'Trees spend a year of sunsets on their pride" ( Day Lewis 169 )--in which the will and creative power of the poets of thirties seemed to have been completely paralysed. Such blankness often marks a prelude to renewed creative activity, and when we recall W.H.Auden's achievement in Look Stranger! this year, his silence appears meaningful. But whatever may have been the source of Auden's despondency, it seemed to have led him beyond the limits of normal experience to the deepest depths of consciousness in which the self was annulled and he confronted the ultimate mystery. He explains this in Look Stranger!:

Hearing of harvests rotting in the valleys,

Seeing at end of street the barren mountains,

Round corners coming suddenly on water,

Knowing them shipwrecked who were launched for islands,

We honour founders of these starving cities;

Whose honour is the image of our sorrow. ( 22 )

Louis MacNeice's Out of the Picture throws little light on the poet's inner life:

March gave clear days,

Gave unaccustomed sunshine,

Prelude to who knows

What dead end or downfall,

O my love, to

Browse in the painted prelude. ( Collected Poems 109)

The distressing memory of Cecil Day Lewis, his physical illness and fatigue, and his inability to do anything with Overtures to Death continued to plague him. He speaks briefly in the poem "February 1936": 
Infirm and grey

This leaden-hearted day

Drags its lank hours, wishing itself away. ( Collected Poems 169)

And Stephen Spender's poem “Thoughts During an Air Raid" points to the conflict of his feelings over the intellectual Auden and the neo-romantic Dylan Thomas: "And drags him to that incommunicable grief / Which is all mystery or nothing" ( The Still Centre 45 ).

Dylan Thomas, on the other hand, dramatizes his experiences, and his experiences are rooted in concrete situations, the reality of life. Vernon Watkins unravels the mystery underlying the success and survival of Thomas's early poems in the midst of intellectual poets of metaphysical tradition:

\section{Not yet! Do not yet bend}

Close to that root so tightly bound

Loosened by creeping waters as they run

Along the fork's rough groin. ( Modern Verse 365 )

Thomas's power of self-analysis is the highest manifestation or development of consciousness, and is man's unique privilege which Auden aims at annihilating and totalizing.

Thomas's 25 Poems (1936) is a quest for truth, and is in this sense allegorical, but his thoughts have the vitality of sensations. Day Lewis defines "the secret process in" Thomas's "brain" aligning with the stream of Hardy and Yeats:

Now, beyond reach of sense and or reason,

His life walks in a glacial sleep

For ever, since he drank that cup

And found it poison.

He's one more ghost, engaged to keep

Eternity's long hours and mewed

Up in live flesh with no escape

From solitude. ( 207 )

The sensibility expressed in Thomas has its poetic ancestry in the individuation of Thomas Hardy and W.B. Yeats, but it is more sophisticated, more urbane, and more complex. What Auden emphasizes is that "Essence without Form is / Free but ineffectual, / Birth and education / Guide the living stream"s ( $L S 69$ ).

In Look Stranger! Auden holds that the structure of Thomas's early poetry shows ${ }^{66}$... traces of intentions not our own" but romantic, "earth's fixtures", "to gravity attentive" ( 14 ) and his achievement is "what our excitement could conceive" ( 15 ). He argues that the "fusion of two elements" ( English Critical Tradition 173 ), thoughts and feelings, "the influential quiet twins ... from whom all property begins" ( $L S$ ) seems to be "an inexact formula" ( ECT 175 ) to Thomas:

But deaf to prophecy or China's drum

The blood moves strangely in its moving home,

Diverges, loops to travel further

Than the long still shadow of the father,

Though to the valley of regret come. ( $L S 28$ )

The poetry of John Donne and others in the metaphysical tradition, whom modern poets regard as their predecessors, is said to have achieved a fusion of thought and feeling. Donne states:

We thinke that Paradise and Calvarie,

Christs Crosse, and Adams tree, stood in one place;

Look Lord, and finde both Adams met in me;

As the first Adams sweat surrounds my face,

May the last Adams blood my soule embrace. ( Metaphysical Poets 90 )

Thought and feeling "are the pieces" in Thomas's poems according to Auden:

You with your charm and your apparatus have abolished

The strictness of winter and the spring's compulsion;

Far from your lights the outraged punitive father,

The dullness of mere obedience here is apparent. ( AT 35 )

Moreover, Thomas's poetry, Auden maintains, conveys thoughts that are translatable into romantic sensations, "dream of islands" ( $L S 23$ ). He holds “ ... sudden death before our eyes ... whose river-dreams long hid the size ... and 
vigours of the sea", "when inland they are thinking their thoughts but are watching these islands" ( 12 ).To Auden the very structure of Thomas's early poetry is "the irresponsible beauty of the stranger", "gaucheness", "the village of the heart", "a licensed house for tourists", "one of the new ... trunk roads", "the thin cafes spring up overnight", " the sham ornamentation, the strident swimming pool" and "the identical and townee smartness" ( 55 ).

The fusion of thought and feeling is unnatural, transcendental and abstract according to Thomas's experiential truth. Watkins describes:

The bud of the apple is already forming there,

The cherry-bud, too, is firm, and behind it the pear

Conspires with the racing cloud. I shall not look.

The rainbow is dividing through the wide-open book

Past the rustling paper of birch, the sorceries of bark. ( $M V)$

What really distinguishes Thomas is a capacity for self-analysis, a capacity for objectifying, and subjecting to analytical scrutiny, one's own experiences and feelings.

What is significant in Thomas's poems is the "originality and intensity with which" his themes related to birth and death, process and decay, sex and redemption are presented. Linda M.Shires, in her study of the poetry of Second World War, estimates that "in their desire to escape rational controls, the Apocalyptics warmed to Thomas' romantic theory of composition. Basing his theory on the image, he suggested a method of composition with obvious connections to Freudian dream psychology" ( 41 ). The Apocalyptics, while giving importance to "inner logic," subjectivity and objectivity, "preferred to impose form on subconscious material, to give it a distinct shape" ( 29-30). Exalting Thomas as a touchstone of success for other Apocalyptic poets, Henry Treece writes that "a terror of the darkness, a fear of hidden things....In bringing them to light the poet teaches himself and some of us, to grapple with them and overcome them" ( 56 ). George Orwell, a socio-political writer, praises Thomas for his "innate talent" of extracting "music from words" and calls him an "almost extinct creature, a lyric poet" ( 315 ). According to Lita Hornick, Thomas "worked from rational principles towards hallucinatory effects of the irrational" ( 42 ). Thomas, while opposing the intellectual trend of Auden's poems, searches earnestly for a system of personal salvation. "He seems to have feared the influence of intellectual upon emotional and sensory experience, and consequently is reluctant to impose too rigorous a cerebral control upon his emotional perceptions and upon his imagery" (Ackerman 43 ).

The critical perspectives on Thomas's early poetry have been unanimous in their observations that what is remarkable in Thomas's 25 Poems is its imagery, rigorous craftsmanship and compression resulting in obscurity and oblique meanings. To quote Watkins, "no poet of the English language had so hoodwinked and confused his critics. None has ever worn more brilliantly the mask of anarchy to conceal the true face of tradition....The most mistaken of his admirers were those who loved it for its novelty" (54). To the readers of modern poetry the early poetry of Thomas "is difficult and obscure in an individual way" (Davies 26 ). Despite several commentaries on the individual poems of Thomas, 25 Poems needs more fresh analysis. The focal point of this study is to establish that the obvious limitations of 25 Poems should not, however, make us ignore its real excellences, and the excellences are many and varied. But the most remarkable advance in Thomas's artistic discipline is marked in the defter handling of dramatic imagination and the underlying pattern of conflicting, incompatible images in the paradoxical structure of Thomas's 25 Poems. To decipher the essential principle of paradox as structure and to decode the much compressed, obscure meaning of 25 Poems is the main objective of this study.

The Apocalyptic poets are hostile to romanticism in their critical approaches but their comments on Thomas have been invariably approbatory. To them, Thomas's early poetry is an imago of paradox, "a home" of "comfort" and faith "the neighbour's strongest wish, to serve and love..." $(L S)$ in which "no one but myself is loved", "time flies on above the dreamer's head, / Flies on, flies on and with your beauty flies. / All things he takes and loses but conceit...( 26 ). Watkins, in seeking to defend Thomas against the disparagement of criticism, devotes himself chiefly to counter Auden's remarks as he finds little need to defend the poetry of Thomas. What modern or metaphysical poetry achieves is not merely "a sensuous" or emotive "apprehension of thought" ( ECT 181); it also achieves a cerebral apprehension of emotion. When Eliot says "a thought to Donne was an experience" ( 183 ), he seems to plead for an enlargement of the area of feeling, implying that the experience communicated in poetry is emotive, sensuous and objective. Watkins explains the womb-tomb process:

White must die black, to be born white again

From the womb of sounds, the inscrutable grain,

From the crushed, dark fibre, breaking in vain. ( $M V 366$ )

What these poets share in common is a heightened awareness in which cerebration and feeling interpenetrate.

However, these characteristics of Thomas's poetry and thought are not enough to explain his reputation in the twentieth century and his appeal to the modern reader. How far can he establish a link between his sensibility and Auden's, and in which way does this sensibility enter into and determine the texture of his poetry? The ambiguity - "white of mute dust", "in the soundfall's greatest light"--in Auden's approach enriches the texture of the juvenile poems and Poems ( 1928 ) and enhances the mystery-"the music in the eyes"-- in Poems ( 1930 ). The poem Look Stranger! is given a 
further dimension of meaning by its ironic, symbolic overtones, "transfiguring whiteness into shadows gone" ( $M V)$. Watkins finds the mysterious secret behind Auden's success and popularity:

In the churchyard the yew is neither green nor black

I know nothing of Earth or colour until I know I lack

Original white, by which the ravishing bird looks wan. ( $M V)$

What is more important to the metaphysical Auden, "black swan" is craftsmanship, "their firemen's hoses" rather than the theme of poetry. "Defence and death being always ... collateral and coaeval" ( $M C P)$.

\section{Discussion}

Irony, inclusiveness, and complexity are the chief criteria of value in the twentieth century intellectual poetry. Watkins explains in the poem "A Foal":

Darkness is not dark, nor sunlight the light of the sun

But a double journey of insistent silver hooves.

Light wakes in the foal's blind eyes as lightning illuminates corn

With a rustle of fine-eared grass, where a starling shivers. ( $M V 368$ )

These criteria, however, do not merely indicate qualities of craftsmanship; they reflect a sensibility, a particular way of experiencing reality.

This "intricacy of engines ... delicacy of darkness" ( $M C P 112$ ) is quite obvious in the poetry of Auden, Day Lewis, Spender, and MacNeice. Watkins affirms:

And whoever watches a foal sees two images,

Delicate, circling, born, the spirit with blind eyes leaping

And the left spirit, vanished yet here, the vessel of ages

Clay-cold, blue, laid low by her great wide belly the hill. ( $M V)$

The searching self-exploration that links Thomas with Auden is more evident in 25 Poems than in his 18 Poems, and in 25 Poems the readers are priviledged to watch his own mental processes. It may be relevant here to quote Thomas's self-criticism and answer:

To-day, this insect, and the world I breathe,

Now that my symbols have outelbowed space,

Time at the city spectacles, and half

The dear, daft time I take to nudge the sentence,

In trust and tale I have divided sense,

Slapped down the guillotine, the blood-red double

Of head and tail made witnesses to this

Murder of Eden and green genesis. ( Poems 139)

It is a commonplace of criticism that Thomas's judgements on his own work and on the work of others are marked by a calm sanity and honesty.

What happens in 18 Poems is that the poet's mind operates simultaneously at two levels, and the readers can witness a co-operation and coalescence of emotion and ratiocination. Watkins observes:

Lovers speak of Venus, and the white doves,

Jubilant, the white girl, myth's whiteness, Jove's,

Of Leda, the swan, whitest of his loves.

Lust imagines him, web-footed Jubiter, great down

Of thundering light; love's yearning pulls hm down

On the white swan-breast, the magical lawn,

Involved in plumage, mastered by the veins of dawn. ( $M V 367$ )

In 25 Poems, the heart is involved in experience and suffers, while an alert intelligence, conscious of itself, analyses and weighs the experience. The result is inclusiveness arising out of a recognition of the complexity of experience, of the pressure of the total context upon a particular situation or mental state: "Mind in the trigger-finger, / And a flight of lead connecting / Self and horizon" (MCP 111$)$.

Thomas's 18 Poems has this quality of paradox in varying degrees, and it is indeed striking that even several of his earlier verses show the juxtaposition and integration of opposed attitudes enriching the poetic texture. "And under the dry, curled parchment of the soil there is always a little foal ... asleep" ( $M V)$. In 25 Poems, as in "I, in My Intricate 
Image," the apparently disorganized flow of thought resembles the stream-of-consciousness technique, but the presence of an alert mind weighing different approaches and directing the journey of life is obvious:

I, in my intricate image, stride on two levels,

Forged in man's minerals, the brassy orator

Laying my ghost in metal,

The scales of this twin world tread on the double,

My half ghost in armour hold hard in death's corridor,

To my man-iron sidle. ( Poems 73 )

The most equal emphases on erotic love and creative quest in 18 Poems present one kind of inclusiveness:

All all and all the dry worlds couple,

Ghost with her ghost, contagious man

With the womb of his shapeless people.

All that shapes from the caul and suckle,

Stroke of mechanical flesh on mine,

Square in these worlds the mortal circle. ( Poems 26 )

Thomas's interest in Day Lewis, Spender, and MacNeice - he shows almost a loving concern for Day Lewis-is equally indicative of his love of contrasts, of chiaroscuro effects, and is not to be confused with Auden's interest in characterization. MacNeice explains:

That people are lovable is a strange discovery

And there are many conflicting allegiances;

The pedals of a chance bicycle

Make a gold shower turning in the sun,

Trains leave in all directions on wild rails

And for every act determined on and won

There is a possible world denied and lost. ( $M C P$ )

Thomas's nature, his curses and his language also attract Spender greatly and he must have been impressed by the design in which the three contraries-Day Lewis, MacNeice, and Spender-are counterpoised and held in unity. Spender explains his vision of heroism in Poems ( 1933 ):

... who in their lives fought for life

Who wore at their hearts the fire's centre.

Born of the sun and they travelled a short while towards the sun

And left the vivid air signed with their honour. ( 46 )

It is this juxtaposition, balancing and integration of contrasts and contraries rather than characterization, conflict and movement pertaining to drama proper that MacNeice seeks and discovers in Thomas's 18 Poems:

Must become the migrating bird following felt routes

The comet's superficially casual orbit kept

Not self-abandoning to sky-blind chutes

To climb miles and kiss the miles of foam

For nothing is more proud humbly to accept,

And without soaring or swerving win by ignoring

The endlessly curving sea and so come to one's home.

And so come to one's peace while the yellow waves are soaring. ( $M C P 46$ )

MacNeice's emphasis is more on the poetry of paradoxes and particularly on the pictorial and sculptural effects of poetry.

Thomas's love of the picturesque, the gorgeous and the dainty, and his appreciation of the almost sculptural symmetry of the words indicate appropriate actions and gestures. MacNeice observes:

May he pick up daintily

The ambiguous joys,

As a bee in May the blossom of fruit

Cross-fertilise his data and distil 
From the drum balalaika fiddle and organ

From sun's gunnery splintering glass

More than the twanging dazzle or the dazzling noise. ( MCP 43 )

What must have gripped MacNeice is the vividness of the phrases building up a subtly-balanced structure of the earthly and the elfin, of the tangible and the ineffable, of movement and motionlessness. Thomas must have been fascinated by these little dramas, complete in themselves, within a drama "to get permanence, to hear the personance ... of all the water-gullies and blackbirds' songs". MacNeice remarks:

To ride two horses at once, a foot on each

Tilting outward on space abstract and packed

With the audience of the dead and the unborn,

To pay his debts to each

To beach his boat so that others can use it

To throw his bread on the waters, the best deposit. ( $M C P 44$ )

Thomas formulates three axioms of poetry in 18 Poems and his formulations are not quite precise and unambiguous. The qualities that he seeks and appreciates in poetry are intensity, spontaneity of feeling and expression, roundedness of imagery, and depth of experience and thought, universal in essence but assimilated into the poet's own consciousness. He states:

One wound, one mind, spewed out the matter,

One breast gave suck the fever's issue;

From the divorcing sky I learnt the double,

The two-framed globe that spun into a score;

A million minds gave suck to such a bud

As forks my eye;

Youth did condense; the tears of spring

Dissolved in summer and the hundred seasons;

One sun, one manna, warmed and fed. ( 58-59)

The axioms show an attempt at a reconcilement of contrary virtues: romantic abundance or magnificence and concentration; spontaneity and constructive ability; adequacy of expressiveness and inexhaustible suggestiveness. Norman MacCaig, an Apocalyptic poet, comments on the inclusiveness as the distinctive, single quality of Thomas's early poems "that have blazed and dazed and wilted" ( $M V 235$ ). He elaborates:

Light perches, preening, on the handle of a pram

And gasps on paths and runs along a rail

And whitely, brightly in a soft diffusion

Veils and unveils the naked figure, pale

As marble in her stone and stilled confusion. ( 236 )

Thomas's early poetry shows that his response to the poetry of Hardy and Yeats is principally confined or directed to these qualities: "I learnt the verbs of will, and had my secret; / The code of night tapped on my tongue; / What had been one was many sounding minded" (Poems ). It is the response of a young, maturing poet to great poetry.

The inclusiveness noted in Thomas's poetry is not really worked out as a conscious design, although his poetic development shows increasing reliance on craftsmanship. MacCaig points out:

A perpetual modification of itself

Going on around her is her; her hand is curled

Round more than a stone breast; and she discloses

The more than likely in an unlikely world

Of dogs and people and stone shells and roses. ( CV 236 )

It stems, on the other hand, from his deep, fundamental honesty, from his keenness to understand the nature of reality and his own inner self in their multiple, conflicting aspects. Day Lewis affirms:

A larger appetite,

A tautening of the will,

The wild pony tamed,

The common gorse alight. ( DCP 201 ) 
In the poems, "The Force that Through the Green Fuse Drives the Flower" and "Before I Knocked," the dual operation of the mind--"the force that through the green fuse drives the flower ... drives my green age; that blasts the roots of trees ... is my destroyer" (127 ), "I who was rich was made the richer ... by sipping at the vine of days" ( 41 )-- arouses a comic perception adding a new flavour to the poignancy of situation and mental state. In 25 Poems, the methods employed to incorporate the disparate elements as also the results achieved are diverse. "So the whole morning he runs here, fulfilling the track ... of so many suns...( $M V 369)$.

In 25 Poems, the poem "The Seed-At-Zero" conveys also convincingly the bobbing motion of the ship, the oscillating mood of Day Lewis, Spender, MacNeice between Thomas and Auden, between "the manwaging line" and "the warwaging line", "the seed-at-zero" and "Man-in-seed, in seed-at-zero", "the trodden womb" and "the manwaged tomb", the "god-in-hero ... divinely stumbling" and "the hero-in-tomorrow divinely leaping", "the star-flanked seed" and "a star-flanked garrison", "a humble village labour" and "a humble planet labour", "a green inch" and "a high sphere", "the foreign fields of space" and "the star-flanked fields of space", and "the sky-scrapping place" and "the grave-groping place" ( Poems 130 ). Watkins points out that it is the technique of inclusiveness that moves the very structure of 25 Poems exploring the mind of Auden and others:

So the whole morning he runs here, fulfilling the track

Of so many suns; vanishing the mole's way, moving

Into moles mysteries under the zodiac,

Racing, stopping in the circle. Startled he stands

Dazzled, where darkness is green, where the sunlight is black.... (MV)

Thomas portrays the complexity reflecting the divided and dilemmatic sensibility of Day Lewis, Spender, and MacNeice between two metaphors, the rhetoric of irony and the wonders of paradox:

And now the horns of England, in the sound of shape,

Summon your snowy horsemen, and the four-stringed hill,

Over the sea-gut loudening, sets a rock alive;

Hurdles and guns and railings, as the boulders heave,

Crack like a spring in vice, bone breaking April,

Spill the lank folly's hunter and the hard-held hope. ( Poems 62 )

While Auden's presence was in a sense agonizing to them, they simultaneously battled against their passion for Thomas and surrendered to him and he helped to a considerable extent to release their poetic rule and energy.

In Spender's The Still Centre, the oppositions are faithfully rendered, and each alternative is questioned and tested: "I with the wooden insect in the tree of nettles, ... in the glass bed of grapes with snail and flower, ... hearing the weather fall." The ecstasy of 25 Poems is far intenser than what fancy could ever achieve: "Spark from the days of energy / And the child hoards it like a bitter toy" ( 66 ). Day Lewis's poems end in tentative resolutions, or in uncertainty that he defends as a value in Hardy, "this is the fortune of manhood" and "no death more natural". In "Overtures to Death", he evaluates that the death-wish expressed in 18 Poems points to a resolution in 25 Poems:

This clay that binds the roots of man

And firmly foots his flying span-

Only this clay can voice, invest,

Measure and frame our mortal best. ( 183 )

What MacNeice aspires to is the unity of experience, and one of the effects of this interfusion of ratiocination and feeling is that the poetic experience ceases to be merely affective. According to the New critic Allan Tate, the language of sentiment like love and politics or war, "mass feeling" and "mass language" which is different from "the language of the people" would make the poet to commit the "fallacy of communication" ( 373 ). "Mass language is the medium of 'communication', and its users are less interested in bringing to formal order what is sometimes called the 'affective state' than in arousing that state" ( 372 ). MacNeice estimates:

And hooked from the mouth like fish

Frame their frolic

Above the silent music

And the awed audience.... ( $M C P 112$ )

Under the influence of Auden, "a phantom hunger" for Auden's popularity and greatness, he breaking "that circle" of his archetypal structure, emphasizes the need for the integration of emotion and intellect, the principle of metaphor in his Poems ( 1935 ), and sometimes he himself tends to use affective terminology, "stooping to drink, to suck" (MV 368). He confirms: 
They rise into the tent's

Top like deep-sea-divers.... ( $M C P)$

But in Out of the Picture, he crushed "the hunger" and the readers can note his disagreement with Auden. He finds that in Poems ( 1930 ), Auden adopts the Hegelian dialectical philosophy to convey his isolation from the normal human scene and from all vital forms of life:

Our fear their frame,

Hallowed by handclaps,

Honoured by eyes

Upward in incense.... (MCP)

The half-sound neologic thinking of MacNeice as a "dry man", "dry lover", "shade", "the dead stir", "the landed crow ... lying low with ruin in his ear", "death hairy-heeled and the tapped ghost in wood" ( Thomas 102 ), and his sound faith in the neolithic paganism--"Let the stones speak ... With tongues that talk all tongues" ( 123 )--are recast in Thomas's poems "Now" and "Shall gods be said to thump the clouds" respectively.

Moreover, Auden's metaphysical structure, the element of cerebration does not result in a shrinkage of feeling; it enlarges the area of sensibility that incorporates intellection and in the process alters the mode of feeling. MacNeice finds to his surprise that believing in Auden's artistic belief is "the belief" that reflects the sensibility of a mystic, the belief in "the self-abnegation of Buddha ... that is disbelieving ... the denial of chiaroscuro ... not giving a damn for existence" ( $M C P 107$ ), that is a disbelief in his experiential, archetypal truth. "Fourfold shadowed / In a crucifixion's / Endless moment" ( $M C P$ ). He reveals the truth behind Auden's poetry, his "principle of indirection" and his rhetoric of "irony as a principle of structure":

$$
\begin{aligned}
& \text { Intricacy of, } \\
& \text { Delicacy of, } \\
& \text { Darkness and engines. ( } M C P \text { ) }
\end{aligned}
$$

Then, as a matter of fact, MacNeice espouses the cause of paradoxical structure of Thomas in lieu of Auden's ironic structure because Auden's metaphysical framework is death-centric, Thomas's paradoxical structure is life-centric. He affirms:

$$
\begin{aligned}
& \text { But I would cherish existence } \\
& \text { Loving the beast and the bubble } \\
& \text { Loving the rain and the rainbow, } \\
& \text { Considering philosophy alien. ( } M C P \text { ) }
\end{aligned}
$$

Auden's ironic strategy reflects indirectly the mythical, monolithic, transcendental and monotheistic reality whereas Thomas's paradoxical poetry refers directly to the actual, archetypal, neolithic, and polytheistic reality. According to MacNeice,

For all the religions are alien

That allege that life is fiction,

And when we agree in denial

The crows in the morning. ( $M C P$ )

In The Earth Compels MacNeice while colliding with Auden, colludes with Thomas. Thomas portrays the journey of the intricate image of MacNeice:

$$
\begin{aligned}
& \text { My images stalk the trees and the slant sap's tunnel, } \\
& \text { No tread more perilous, the green steps and spire } \\
& \text { Mount on man's footfall, } \\
& \text { I with the wooden insect in the tree of nettles, } \\
& \text { In the glass bed of grapes with snail and flower, } \\
& \text { Hearing the weather fall. ( Poems } 72 \text { ) }
\end{aligned}
$$

And it is in this "fidelity to thought and feeling" ( ECT 180 ), in this dramatization of the creative dilemma, that MacNeice departs from the metaphysical, Audenesque structure and comes closer to the paradoxical structure and the archetypal tradition of Thomas, "the natural parallel" ( Poems ). According to MacNeice, the ecstasy of 25Poems is brief, but it gives him a sudden glimpse into the nature of pure, unalloyed bliss that art, beauty, and fame could never afford:

Our freedom as free lances

Advances towards its end;

The earth compels, upon it 
Sonnets and birds descend;

And soon, my friend,

We shall have no time for dances. ( 104 )

In distinguishing between the ironic structure of Auden and the paradoxical structure of Thomas, Watkins remarks that the difference is between the intellectual poet, "shaped to her shining, pricked into awareness .... by the swinging dug" and the reflective poet, "vaulted with a beautiful hero's back ... arched under the singing mane" ( $M V)$ who escapes from "a world of aery technic" (MCP), "the fear of loneliness ... and uncommunicableness" ( $M C P 94$ ) to "the boundless horizons of air" ( $M V$ ) for " our prerogatives as men ... will be cancelled who knows when... ( $M C P 95$ ). When poetry is viewed in the metaphysical perspective that achieves not merely an emotive or "a sensuous apprehension of thought" , "searching for the lost handle to the silent fountain" but also a cerebral apprehension of emotion, "hiding in the shrubbery, shutting our eyes and counting", MacNeice holds, the separation between the language of emotion and the language of discourse, the language of irony as "a principle of structure" and "the language of paradox" as "a principle of structure", "the games with puffball and plantain", the "noise of the corncrake railing" and "the marigolds parading", "the gay martyrdom, the brave fantasia" and "the dive in love's lagoons of brilliant azure", "the kick of inspired religion, the noise of the moving nations" and "the visions in drink, the feel of the homing pigeon" ( MCP 94 -95) loses validity. To Thomas, 18Poems stands paradoxical in structure reflecting the "grammatology" of poetry and fellow-feeling, "freedom was flesh and blood" ( DCP 200 ), and his 25 Poems reveals itself paradox as a principle of structure. This principle of "freeplay" and "mortal body" is more than wit and irony, more than the language of the soul and the language of intellect. "Freedom was more than a word, more than the base coinage ... of politicians who hiding behind the skirts of peace ...they had defiled, gave up that country to rack and ruinage" ( $D C P$ ). As Cleanth Brooks puts it, "our prejudices force us to regard paradox as intellectual rather than emotional, clever than profound, rational rather than divinely irrational ( 292 ).

Thus in the cold war of rhetorics, between irony and paradox, between Auden and Thomas, between "floods and voluble winds" in waving "their magic wands", in warning "the dead away", "in swaying copse", Day Lewis, Spender, and MacNeice flowed on the warmer currents of Thomas, "the bee finds the pollen, ... the pale boy a cure" ( $D C P$ ). By comparison, Auden perceives that human achievements and the conceptions of the brain, "the reason's gift", "the intricate ways of guilt" seem trivial, just "love raging for the personal glory" ( $L S 17$ ) and "nurse's flowers will not last" ( 24 ). He adds:

Our hunting fathers told the story

Of the sadness of the creatures,

Pitied the limits and the lack

Set in their finished features.... ( 17 )

But in Auden's Look Stranger!, there is a stark realization that so long as the poet is condemned to the condition of mortality, "nothing remained", he would never know the answer:

Others have tried it, all delight

Sustained in that ecstatic flight

Could not console

When through exhausting hours they'd flown

From the alone to the Alone,

Nothing remained but the dry-as-bone

Night of the soul. ( 36 )

The poem ends on this note of despair and bafflement analogous to George Herbert's ignorance in the poem "Affliction": "But with my years sorrow did twist and grow, / And made a partie unawares for wo" ( MP 122 ).

In Auden's poems, the comic element is absent, and the analytical mode increases the poet's or, the speaker's perplexities and deepens the tragic vision. Thomas evaluates:

Intricate manhood of ending, the invalid rivals,

Voyaging clockwise off the symboled harbour,

Finding the water final,

On the consumptives' terrace taking their two farewells,

Sail on the level, the departing adventure,

To the sea-blown arrival. ( Poems)

The comic paradoxical role of Thomas is analogous to Autolycus's in The Winter's Tale while the tragic ironic play of Auden to Hamlet's in Hamlet.

In Auden's poetry, the aesthetic effect of rhetoric of irony may be a deepening of poignancy. His vision, again, may be ironic, and his device of irony has many forms. In the juvenile poems of Auden, the felicity proves deceptive, and the 
pattern of cosmic irony, of sleep, dream and awakening carries a different significance. He enjoys moments of rare happiness in Walter de la Mare's company; but his dream is a terrible nightmare, and when he awakens to reality he finds himself forlorn. Thomas states:

We in our Eden knew the secret guardian

In sacred waters that no frost could harden,

And in the mighty mornings of the earth;

Hell in a horn of sulphur and the cloven myth,

All heaven in the midnight of the sun,

A serpent fiddled in the shaping-time. (Poems)

His predicament is partly analogous to that of John Donne choosing "an Everlasting night" to escape "stormy days "and "to see God only" ( 89 ) in the poem "A Hymne to Christ, at the Authors last going into Germany" ; George Herbert's "Prayer" and Walter de la Mare's "Nocturne" are the more obvious analogues. Detached perception of ones own predicament may sharpen the sense of incongruity, and in such situations, the comic sense blends with the tragic. Again, although the visionary bliss is elusive and even a delusion, there is an implicit recognition of its value. The attitude of Auden ceases to be affirmative in Poems ( 1928 ); the awareness of disparate elements and contrarieties complicates response and prevents any simple resolution. T.S.Eliot's "The Lovesong of J.Alfred Prufrock", "Preludes", and "Sweeney among the Nightingales" are identical examples to illustrate the state of mind of Auden and his unstable irony.

The design may be inclusive in Poems ( 1930 ) in another sense. Two sets of characters representing contrary approaches may be incorporated in the dramatic structure, and the suggestion is that reality includes both horror and glory, beauty and ugliness analogous to the stable irony of Eliot's The Waste Land. Thomas maintains:

When we were strangers to the guided seas,

A handmade moon half holy in a cloud,

The wiseman tell me that the garden gods

Twined good and evil on an eastern tree;

And when the moon rose windily it was

Black as the beast and paler than the cross. (Poems)

If the ironic device produces a delicate equilibrium analogous to the structural irony of Eliot's "Ash Wednesday", it may also help the poet Auden reach forward through a maze of contradictions to a positive state in Look Stranger! The vision is tested and questioned, and it may finally survive the fires of experience and ratiocination. Thomas explains:

Incarnate devil in a talking snake,

The central plains of Asia in his garden,

In shaping-time the circle stung awake,

In shapes of sin forked out the bearded apple,

And God walked there who was a fiddling warden

And played down from the heavens' hill. ( Poems )

Thomas equates Auden's rhetoric of irony with that of Milton's Satan in the Garden of Eden tempting Eve to taste the forbidden apple.The garden to which his contemporary poet is led represents at one level the realm of deceptive enchantment, but at another level it symbolizes the visionary realm of imagination, "the unrisen wonder ...in the path of the dead, fallen from the sun in her hooves ... and eluding the dead hands, begging him to play" ( $M V 369$ ). However, uncertainty and unresolved tension are more characteristic of Auden's poetry than affirmation and faith, and the term irony has a special relevance in this context.

The early poetry of Auden's contemporaries may be visionary and deceptive, but its beauty has a validity of its own. It was Auden who had shaped their sensibility and fostered their vision and craftsmanship. The great fault of a modern school of poetry is an overflow of natural sensibility, human passion, imaginary splendour, and devouring egotism. Auden did not so understand poetry:

Which cannot see its likeness in their sorrow

That through them desperate to the brink of valleys;

Dreaming of evening walks through learned cities,

They reined their violent horses on the mountains,

Those fields like ships to castaways on islands,

Visions of green to them that craved for water. ( LS 22) 
Auden had before him three norms or ideals: amplitude and largeness represented by Walter de la Mare; the dramatic ideal represented by T.S.Eliot. The poetry of Auden that probed the human heart and conveyed the mystery of existence is endowed with all these qualities:

Hearing of harvests rotting in the valleys,

Seeing at end of street the barren mountains,

Round corners coming suddenly on water,

Knowing them shipwrecked who were launched for islands,

We honour founders of these starving cities,

Whose honour is the image of our sorrow. ( $L S$ )

Auden's censure of contemporary poetry and his praise of the founders of his poetry bear the unmistakable stamp of Eliot's theory of poetry. "Poetry is not a turning loose of emotion, but an escape from emotion; it is not the expression of personality, but an escape from personality" ( $E C T)$.

Thomas's poem "Foster the Light" gives an exposition of this:

Foster the light or veil the manshaped moon,

Nor weather winds that blow not down the bone,

But strip the twelve-winded marrow from his circle;

Master the night nor serve the snowman's brain

That shapes each bushy item of the air

Into a polestar pointed on an icicle. ( Poems 57 )

In the next four stanzas, given in poetwise order, Thomas brings out their varying attitudes to Auden at different phases and also indicates his attempt in clarifying the direction that his own poetry should take.

In Beechen Vigil ( 1925 ), Day Lewis is visionary and impressionistic of his personal experiences. He admits in Transitional Poem ( 1928 ):

My lover of air, like Artemis

Spectrally embraced,

Shuns the daylight that twists her

To mineral distaste. ( $D C P 17$ )

It was Auden who forced Day Lewis to learn the width and objectivity of poetry. And Day Lewis's emphatic rejection of his personal impressions is obviously seen in the next volume of verses, Country Comet ( 1926 ) "of an intransigent nature ... and the betraying smile" ( $L S 32$ ). Day Lewis gives thanks to Auden, "yet had there not been one hostess ... ever whose arms waylaid ... like the tough bramble a princeling's journey...( $D C P 19)$. He sees his initial journey from "murmur of spring" to "farmer in time of frost", from "the cockerel's eggs" to "the burning leagues", "a season in the figs" to "the seeds of snow", "four-fruited ridings" to "red-eyed orchards", and from "the vegetable century" to "your country" ( Thomas Poems ) as a preparation for his active creative mind. Day Lewis compares and contrasts the two books : "So the antique balloon / Wobbles with no defence / Against the void but a grapnel that hops and ploughs / Through the landscape of sense)" ( DCP ). While Beechen Vigil was "nothing", "the loss major", Country Comet was "his thinning hair ... and his hauteur", "the profits larger" $(L S)$.

Spender, rejecting his Shelleyan romanticism in his Nine Experiments ( 1928 ), favours the Audenesque impersonality in Twenty Poems ( 1929 ). He says in a dismissive tone:

Cancel that heaven and abyss

Whose blues and reds roar back to madness,

Avoid these chasms and steep gaps in space,

Sense should grope on all fours....(19)

His transformation from private mind to public spirit, from political mind to allegorical form is variously imaged in Thomas's poem as "the fly-lord's acre" to "high lord squire", "a goblin sucker" to "the ninnies'choir", "your wizard's ribs" to"mortal voices", "the heart-shaped planet" to "the singing cloud", "a mandrake music" to "sprout on owl-seed", and "from the marrowroot" to "father all" ( Poems).

Auden's view of MacNeice's poetry was to a great extent coloured by his dislike of the taint of egotism in MacNeice's character in Blind Fireworks ( 1929 ). MacNeice appealed to Auden in the early phase as a poet of serene natural beauty, but during his meeting at Oxford he was struck by Auden's dramatic ideal and his insistence "on the need for stroking and advice".

Like the calm blue marriage of the sky and sea,

Or a blue-veiled Madonna beaming vacancy,

See that Madonna snuff out the shaded light 
And stroke with soothing hand asleep the night. ( MCP 61 )

MacNeice's Poems (1935) emphasizes the religious implications of Auden's Poems (1930), especially the poem "It was Easter as I walked in the public gardens" but for MacNeice the feeling produced by the lines was appalling. What must have stirred MacNeice's imagination is evident from his own comments:

$$
\begin{aligned}
& \text { He is afraid of God and the Devil- } \\
& \text { If he shuts his eyes they will draw level, } \\
& \text { So he watches the half-open door and waits } \\
& \text { For people on the stairs carrying lights. ( } 85 \text { ) }
\end{aligned}
$$

Thomas's poignant rendering of the mind's bafflement at the mystery of existence, the mind's anxieties because of its failure to comprehend reality rolls as a "shift" from all my mortal lovers" to "the cross-boned drift", from "the bowand-arrow birds" to "ring of seas", and from "this turning tuft" to "a tufted axle" ( Poems ).

So, it is obvious that Thomas, like most other admirers of Auden, regards Auden's poetry as a message of hope and salvation to his contemporaries; and Thomas himself is quite explicit in his profession of faith in them:

Who gave these seas their colour in a shape,

Shaped my clayfellow, and the heaven's ark

In time at flood filled with his coloured doubles;

$\mathrm{O}$ who is glory in the shapeless maps,

Now make the world of me as I have made

A merry manshape of your walking circle. ( Poems )

Echoing Auden, Thomas had censured in 18 Poems the morbid element in the poets of thirties, and they turned to Thomas's 25 Poems as "glory", their world of hope and salvation, but his aesthetic had undergone a steady transformation by the time he had been composing the third book of The Map of Love. The phenomenon that strikes Thomas most in contemporary culture is the shifting of interest to the inner reality of the human heart behind all encrustations; the evolutionary progression as envisaged by him is from amplitude to depth, from comparative simplicity and innocence to increasing complexity, from elementary consciousness to greater degrees of selfconsciousness.

Thomas, thus, projects in 25 Poems his own inner reality and the creative perplexities of Auden and others, and he belongs, in the main, to the neo-romantic tradition. And yet he has survived the intellectual crusade and totalization of Auden, and as MacNeice observes, his stature has even been elevated: "Bric-a-brac ... pick-a-back ... spillbucket ... splits" ( MCP 114 ). Thomas's 18 Poems reveals itself as a testament of crucifixion and redemption and his 25 Poems as a sacrament of communion. On the whole, Thomas's early poetry reflects the sensibility of paradox as structure which, in turn, reveals the reality of existence and co-existence and Thomas as a redeemer.To Day Lewis, Thomas's early poetry is a paradox:

\section{But dearer still to see}

Those shores insured for life from the shadow of tyranny,

Freedom was not on their lips; it was what made them endure,

A steel spring in the yielding flesh, a thirst to be free. ( DCP 198 )

Thomas achieves self-realization through the process. His early poetry renders this journey of his mind; and his rendering gains in depth as he has undergone the whole journey himself and assimilated the universal experience into his own personal consciousness. This explains why Thomas is deeper than Auden; Auden's metaphysical, ironic concept of freedom can be learnt through study but Thomas's atheistc, aesthetic idea of freedom demands a different kind of understanding - the reader must be able to experience his vision.

\section{Conclusion}

So Thomas's simultaneity of participation and dissociation, of involvement and dissection explains the many paradoxical heterogeneities in tone and idiom in his 18 Poems: "Mortal these words and the deed they remember, but cast a seed / Shall flower for an age when freedom is man's creative word" ( DCP 200 ). In 25 Poems, there is the combination of earnest commitment and amused detachment, of levity and profundity, of the language of logical discourse and the language of intense feeling, “... yet the battle's height / Raised it to love's meridian and held it awhile immortal... ( $D C P$ ). The other features of Thomas's poetry - the quick shifts of tone and attitude, the telescoping of images and heterogeneous associations, the dramatization of experience --may all be subsumed under the major premise of his next volume of poems and stories, The Map of Love. "In the uttermost darkness of a vase / There is still the print of fingers, the shadow of waters" $(M V)$. 


\section{References}

Ackerman, John. Dylan Thomas: His Life and Work. London: Macmillan, 1964. Print.

Allott, Kenneth, ed. Contemporary Verse 1918-60. Harmondsworth: Penguin, 1962. Print.

Auden, W.H. Poems. London: Faber, 1930. Print.

---. Look Stranger! London: Faber, 1936. Print.

---. Another Time. London: Faber, 1940. Print.

Brooks, Cleanth. "Irony as a Principle of Structure." S, Ramaswami and V.S. Sethuraman, Eds. The English Critical Tradition: An Anthology of English Literary Criticism Vol.2 Macmillan: Madras, 1978. Print.

Davies, Walford. Dylan Thomas .New Delhi: Viva Books, 2003. Print.

Day Lewis, Cecil. Collected Poems 1929-1954. London: Hogarth-Cape,1954. Print.

Eliot,T. S. "Tradition and the Individual Talent." S, Ramaswami and V,S, Sethuraman, Eds. The Englih Critical Tradition: An Anthology of English Literary Criticism Vol.2 Macmillan: Madras, 1978. Print.

---. "The Metaphysical Poets." S, Ramaswami and V,S, Sethuraman, Eds. The Englih Critical Tradition: An Anthology of English Literary Criticism Vol.2 Macmillan: Madras, 1978. Print.

Gardner, Helen, ed. The Metaphysical Poets. London: Penguin, 1975. Print.

Hornick, Lita. “The Intricate Image.” Disseration. Columbia University, 1958.

MacNeice, Louis. Collected Poems 1925-1948. London: Faber, 1949. Print.

Orwell, George. Review. The New Apocalypse, Life and Letters To-day xxv. June 1940: 315-18. Print.

Roberts, Michael, ed. Modern Verse. London: Faber, 1951. Print.

Shires, M. Linda. British Poetry of the Second World War. London : Macmillan, 1985. Print.

Spender, Stephen. Twenty Poems. Oxford: Basil Blackwell, 1930. Print.

---. The Still Centre. London: Faber, 1939. Print.

Tate, Allen. "Tension in Poetry." S, Ramaswami and V,S, Sethuraman, Eds. The Englih Critical

Tradition: An Anthology of English Literary Criticism Vol.2 Macmillan: Madras,1978. Print.

Thomas, Dylan. Poems. London: Hunter, 2004. Print.

Treece, Henry. Dylan Thomas. New York: Graff, 1956. Print.

Watkins, Vernon. "Innovation and Tradition.” The Times 10 June 1953. Print. 